\title{
KONSEP FLOATING PLATFORM PADA RUMAH TINGGAL DI PANTAI MUTIARA, JAKARTA UTARA
}

\author{
Jaclyn Christevi Octavia ${ }^{1}$, Heru Sufianto ${ }^{2}$, Bambang Yatnawijaya $\mathrm{S.}^{\mathbf{3}}$ \\ Jurusan Arsitektur Fakultas Teknik Universitas Brawijaya, Malang \\ Jl. Jl. MT Haryono No. 167 Malang \\ *Email: ${ }^{1}$ jaclynjco@gmail.com
}

\begin{abstract}
Flood in flood prone area may degrades the quality of building materials, especially those made from timber and steel. Number of strategies for preventing flood have been implemented, including canal system, water dam, and infiltration affected region. This study seeks available modification of structural system implemented for individual residential building. The flood proof housing system was found to be effective installed in pantai mutiara housing area, North Jakarta. Some of supported materials has been choosen by consideration of materials weight, such as light steel as the main column, casco as the buoyancy system. This structural system modification concept also equipped by bump as the reservoir container of floodwater, and filtration tank to protect the whole system performance from dirt.
\end{abstract}

Keywords: Floating Platform, Floating Residential, Flood.

\section{PENDAHULUAN}

Wilayah Jakarta Utara memiliki ketinggian permukaan tanah yang cukup rendah (0-2 meter di atas permukaan laut). Sebagian besar areal Jakarta utara merupakan wilayah pantai beriklim panas $\left( \pm 28,7^{\circ} \mathrm{C}\right)$, dengan curah hujan 135,93 $\mathrm{mm} /$ bulan, dan curah hujan maksimal terjadi pada bulan Januari. Kelembaban udara umumnya mencapai $74,7 \%$ yang disapu angin sekitar $8.8 \mathrm{~km} / \mathrm{jam}$ sepanjang tahun. Dengan kondisi iklim dan karakter geografisnya, wilayah Jakarta Utara sering kali terkena dampak banjir. Banjir tersebut secara lambat laun akan berdampak buruk terhadap kelaikan konstruksi bangunan, diantaranya, terjadinya degradasi material bangunan. Pada kajian ini pendekatan penyelesaian masalah banjir didekati dengan penyelesaian rekayasa sistem struktur bangunan. Teknologi floating platform dipilih sebagai salah satu alternatif solusi.

\section{METODE PENELITIAN}

Informasi awal dibutuhkan untuk pendekatan type struktur floating system yang akan digunakan, antara lain: pel ketinggian banjir dari tahun ke tahun, upaya penghuni bangunan dalam mengatasi banjir, jenis material kontruksi rumah eksisting di wilayah studi dan typikal rumah yang ada. Informasi itu dikumpulkan melalui serangkaian survey lapangan dan wawancara baik terhadap warga sekitar lokasi studi, pengelola perumahan maupun unsur muspika. Data terkumpul di analisa baik secara kuantitatif maupun kualitatif. Hasil analisa diuraikan secara deskriptif.

Beberapa jenis data sekunder juga digunakan dalam penelitian ini, antara lain karya tulis terkait, peraturan bangunan setempat, data kepadatan bangunan dan penduduk (Jakarta dalam angka 2013) dan beberapa sumber online, misalnya: www.jakarta.go.id.

\section{HASIL DAN PEMBAHASAN}

\section{Teknologi Floating System}

Beberapa negara telah menerapkan hunian berbasis air. Berikut pada Tabel 1 . Diuraikan beberapa jenis teknologi floating system yang telah diterapkan pada hunian berbasis air. 
Tabel 1. Beberapa Teknologi Floating System

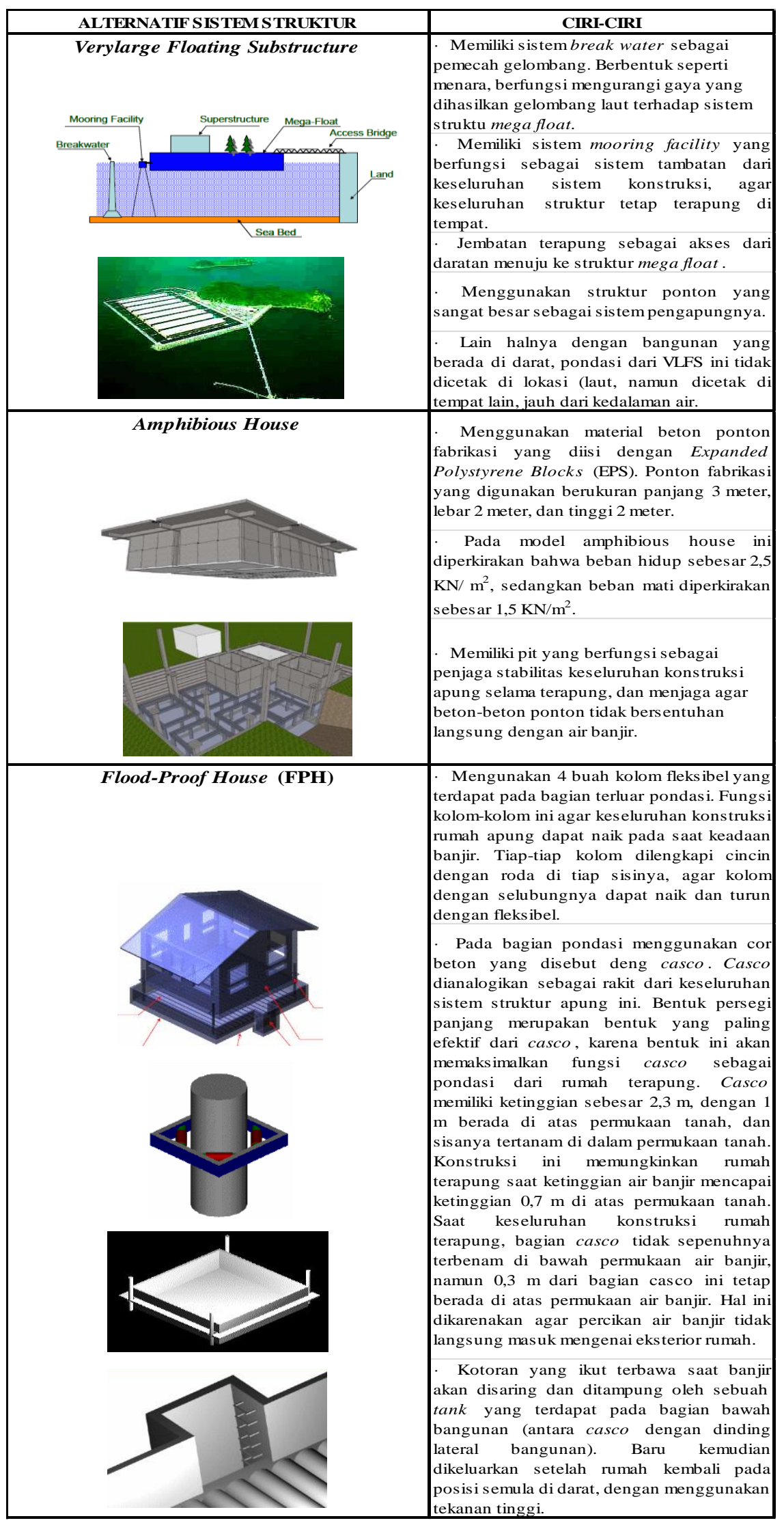




\section{Wilayah Studi}

Kondisi topografis wilayah Jakarta Utara menjorok ke darat antara 4-10 km. Tipe rumah yang berada pada kawasan ini beragam, luas rumah pada kawasan ini berkisar antara $135 \mathrm{~m}^{2}$ hingga $1.200 \mathrm{~m}^{2}$.
Kawasan perumahan ini dikelilingi oleh laut. Berikut pada Gambar 1. Merupakan peta persil wilayah kajian.

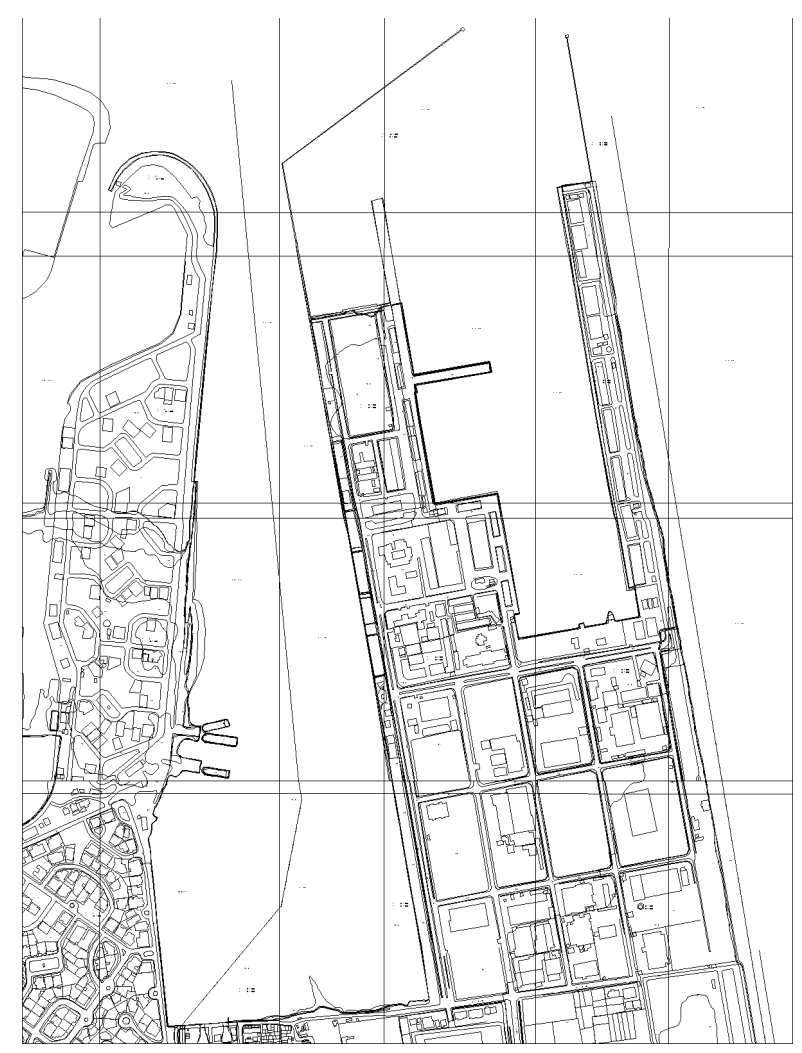

Gambar 1. Peta Persil Kawasan Pantai Mutiara, Jakarta Utara Sumber: Dokumentasi Dinas Tata Ruang dan Tata Kota DKI Jakarta

Hasil survey lapangan yang dilakukan pengelola kawasan perumahan Pantai Mutiara semenjak tahun 2007, diperoleh data grafik pasang laut yang menunjukkan bahwa setiap tahunnya ketinggian air laut semakin meningkat. Ketinggian air di kawasan Pantai Mutiara saat banjir terjadi, berkisar antara 1,97 hingga 3,4 meter. ketinggian banjir terendah terjadi pada tahun 2007 yaitu setinggi 1,97 meter, sedangkan ketinggian banjir tertinggi terjadi pada tahun 2011 dan 2012 dengan ketinggian sebesar 3,4 meter. Jikadiuraikan, pada tahun 2007 banjir terendah terjadi pada bulan Oktober dengan ketinggian 1,97 meter dan banjir tertinggi terjadi pada bulan November dengan ketinggian 2,95 meter.

Pada tahun 2008, banjir terendah terjadi pada bulan Februari dan Maret dengan ketinggian 2,15 meter, sedangkan banjir tertinggi terjadi pada bulan Desember dengan ketinggian 3,13 meter. Pada tahun 2009 banjir terendah terjadi pada bulan April dengan ketinggian banjir 2,35 meter, sedangkan banjir tertinggi terjadi pada bulan Mei dengan ketinggian banjir mencapai 3,25 meter. Pada tahun 2010, banjir terendah terjadi pada bulan April dengan ketinggian banjir mencapai 2,3 meter, dan banjir tertinggi terjadi pada bulan Oktober dan November dengan ketinggian banjir 3,25 meter. Pada tahun 2011, banjir terendah terjadi pada bulan September dengan ketinggian 2,5 meter, sedangkan banjir tertinggi terjadi pada bulan November dengan ketinggian banjir mencapai 3,4 meter. Pada tahun 2012 banjir terendah terjadi pada bulan Maret, dengan ketinggian banjir mencapai 2,5 meter, sedangkan banjir tertinggi terjadi pada bulan Desember dengan ketinggian mencapai 3,4 meter. Pada tahun 2013, banjir terendah terjadi pada bulan Maret dengan ketinggian banjir 
mencapai 2,5 meter, sedangkan banjir tertinggi terjadi pada bulan Juni dan Oktober dengan ketinggian mencapai 3,38 meter. Pada tahun 2014, banjir terendah terjadi pada bulan Maret dengan ketinggian banjir 2,45 meter, sedangkan banjir tertinggi terjadi pada bulan Juni, Juli, dan
Agustus dengan ketinggian banjir mencapai 3,3 meter. Berdasarkan data banjir tersebut, dapat disimpulkan bahwa rata-rata kenaikan ketinggian air laut setiap tahunnya mencapai $0.04 \%$ (Gambar 2).

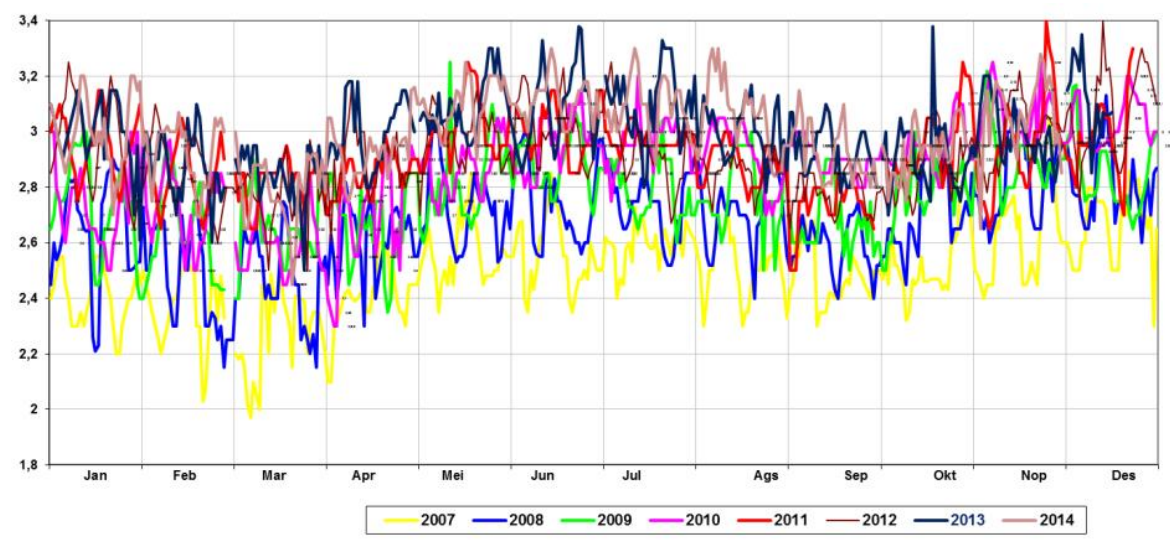

Gambar 2. Grafik Pasang Laut

Sumber: Data Survei PT. Intiland Pantai Mutiara, Jakarta Utara

Struktur pada kajian ini terbagi atas 3 bagian, yaitu substructure, middle structure, dan upper structure. Berikut akan dibahas mengenai setiap komponen dari tiap-tiap bagiannya.

\section{Substructure}

Pada lapisan paling dasar (Gambar 3), substructure menggunakan slab dengan ketebalan sekitar $410 \mathrm{~mm}$ yang berfungsi sebagai pijakan kolom-kolom baja dari rumah terapung tersebut. Di atasnya, direncanakan sebuah wadah yang berfungsi sebagai tempat endapan sementara kotoran yang masuk bersama aliran air banjir (bump) terdapat beton casco. Casco digunakan sebagai rakit atau pengapung dari keseluruhan sistem rumah terapung. Casco terbuat dari beton prategang, dengan material yang kedap air.

Casco, bump, dan slab menggunakan bahan beton prategang (reionforcedconcrete). Bahan ini digunakan berdasarkan tinjauan studi komparasi terhadap jurnal Design Studies on Flood-Proof House menggunakan casco yang di desain sesuai standar British Standards 8110: Structural Use of Concrete, juga 8007: Design of Concrete Structures for Rataining Aqueous Liquids.

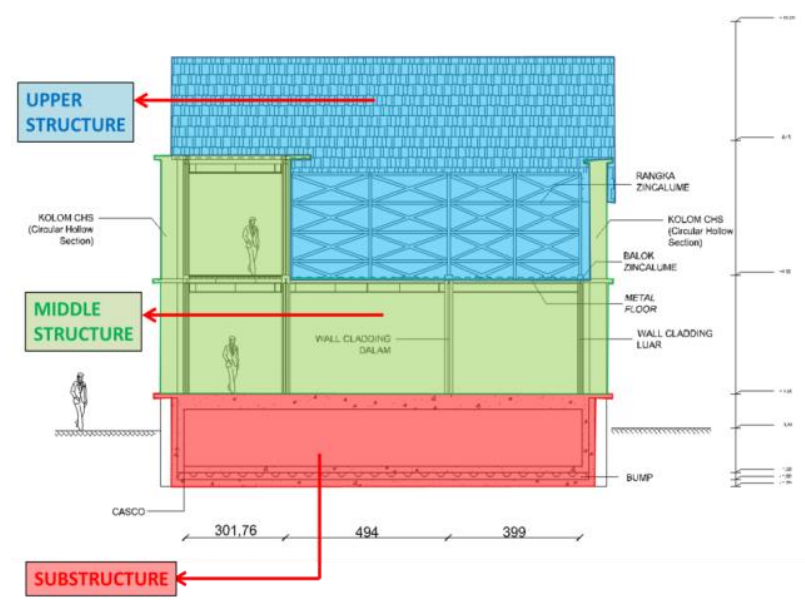

Gambar 3. Bagian-bagian Bangunan 


\section{Middle Structure}

Kolom pada desain ini menggunakan dua jenis material, yaitu Circular Hollow Section (CHS) dan baja ringan zincalume tipe Wf. Kolom yang menggunakan baja CHS (Circular Hollow Section) dengan diameter $508 \mathrm{~mm}$, ketebalan 12,5 mm dan tinggi $12,2 \mathrm{~m}$, berguna sebagai kolom struktural, sekaligus sebagai tambatan dari rumah apung saat rumah bergerak secara vertikal pada waktu banjir terjadi. Kolom ini juga dilengkapi dengan ring yang berfungsi sebagai pengikat antara casco dengan kolom.Ring dilengkapi dengan roller yang terbuat dari baja, dan dilapis oleh roller plastik, yang memungkinkan pergerakan vertikal rumah terapung, dan berguna mengurangi gesekan antara ring dengan kolom baja (Gambar 7-13). Kolom struktural diperkuat dengan $X$ bracing structures guna mereduksi gaya lateral yang ditimbulkan oleh gelombang air banjir. Struktur ini bertugas mempertahankan kekakuan keseluruhan konstruksi bangunan, serta menjaga kestabilan posisi bangunan saat bangunan terkena dampak oleh gaya yang ditimbulkan oleh air banjir, maupun pada saat bangunan terkena angin.Kolom yang menggunakan zincalume tipe Wf berfungsi sebagai kolom praktis.

Penggunaan wall cladding dengan jenis stoneveener dipilih sebagai penutup dinding interior dan jenis metalcladding sebagai penutup dinding eksteriornya.Pada saat banjir, terjadi perbedaan ketinggian antara muka tanah dengan dasar rumah. Oleh karena perbedaan ketinggian ini, maka diperlukan sebuah ramp yang mengadaptasi sistem ramp door kapal, yang dapat fleksibel mengikuti pergerakan konstruksi rumah apung saat bergerak vertikal pada waktu banjir terjadi.

\section{Upper Structure}

Zincalume dipilih sebagai material rangka atap maupun material penutup atap, dikarenakan karakter zincalume yang ringan, kuat, dan awet. Rangka atap diperkuat dengan $X$ bracing structures yang memperkuat struktur atap, mengingat lokasi kajian berada pada wilayah pesisir pantai dengan tekanan angin yang cukup kuat.

\section{Sistem Utilitas}

Bio tank digunakan sebagai septic tank pada rumah terapung. Bio tank diletakkan pada ruang dalam casco, di bagian bawah rumah. Penggunaan bio tank sebagai septic tank ini didasarkan atas pertimbangan bobotnya yang ringan.

Air banjir membawa kotoran padat, untuk itu diperlukan sebuah filter yang menyaring kotoran yang masuk pada bagian pondasi rumah saat banjir terjadi. Pengaktifan pipa kapiler dibantu dengan buoy valve. Pada saat air banjir surut, pelapung pada buoy valve akan secara otomatis turun dan membuka katup untuk mengaktifkan pipa-pipa kapiler, dan menggelontor keluar kotoran pada daerah bump ke arah filtration tank. Setelah kotoran masuk ke dalam filtration tank, kemudian kotoran dapat diangkat secara manual.

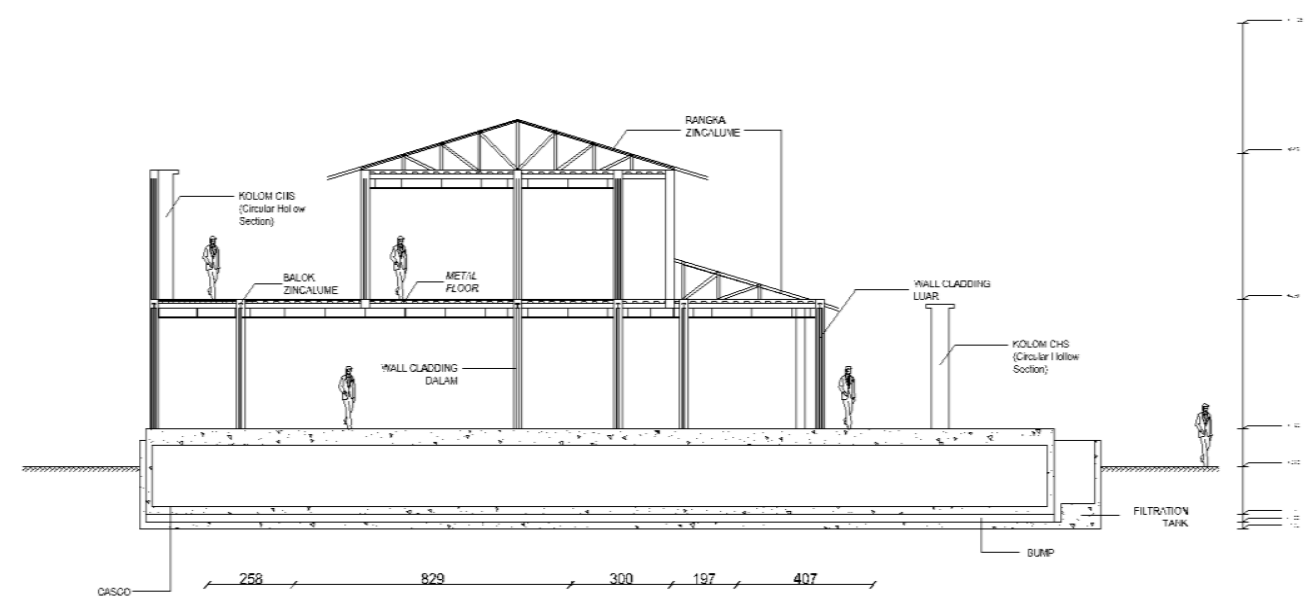

Gambar 4. Potongan B-B' 
Untuk menghindari terjadinya konsleting pada saluran elektrikal, digunakan sebuah pipa fleksibel (Gambar 5). Pipa fleksibel ini juga dapat digunakan sebagai pipa untuk saluran pendistribusian kebutuhan air bersih dari luar bangunan ke dalam bangunan (Gambar 6).

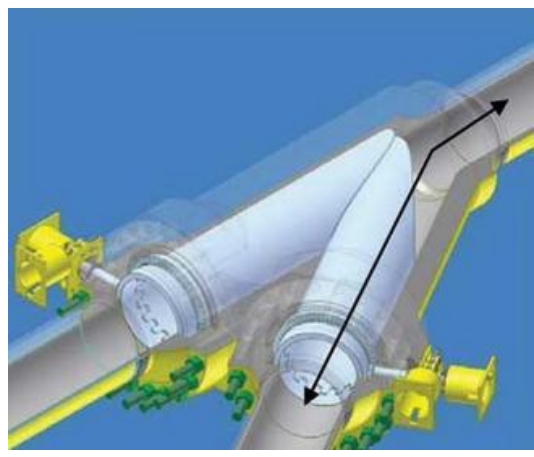

Gambar 5. Detail Pipa Fleksibel Sumber: www. anggraenieka.wordpress.com

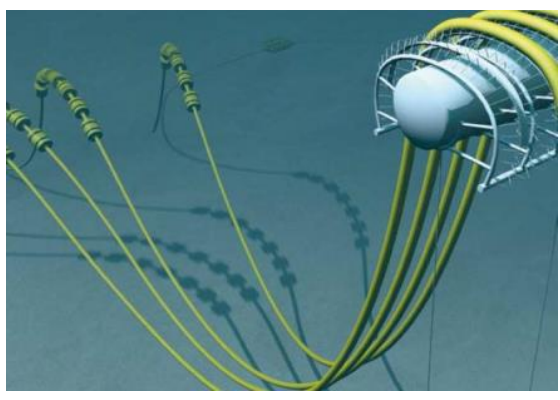

Gambar 6. Contoh Penggunaan Pipa Fleksibel Sumber: www. anggraenieka.wordpress.com

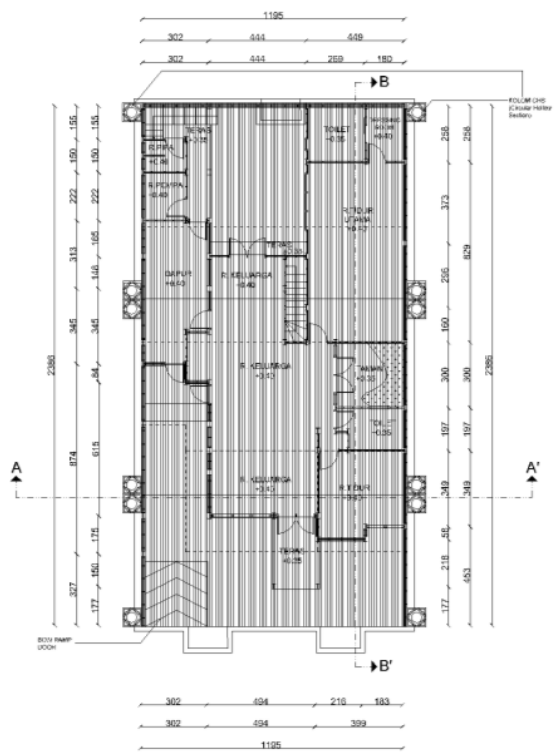

Gambar 7. Denah Lantai 1

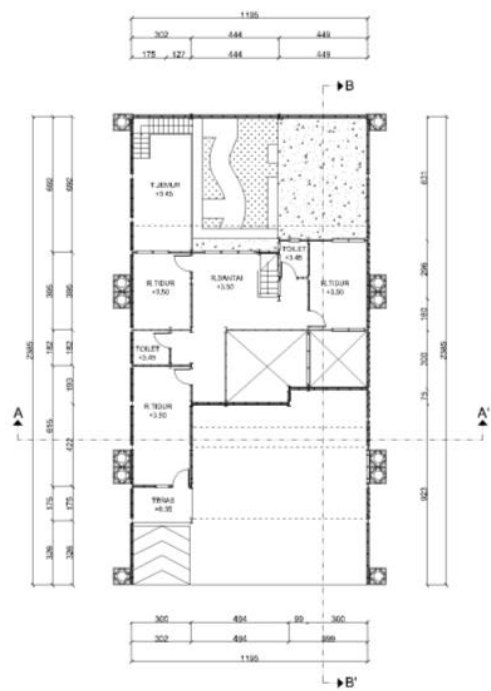

Gambar 8. Denah Lantai 2
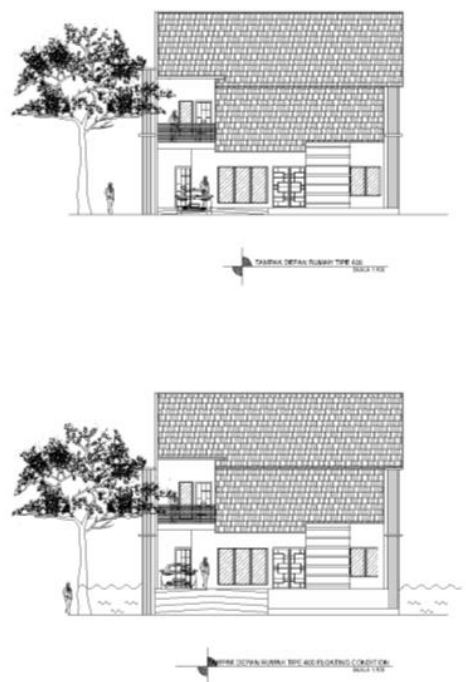

Gambar 9. Tampak
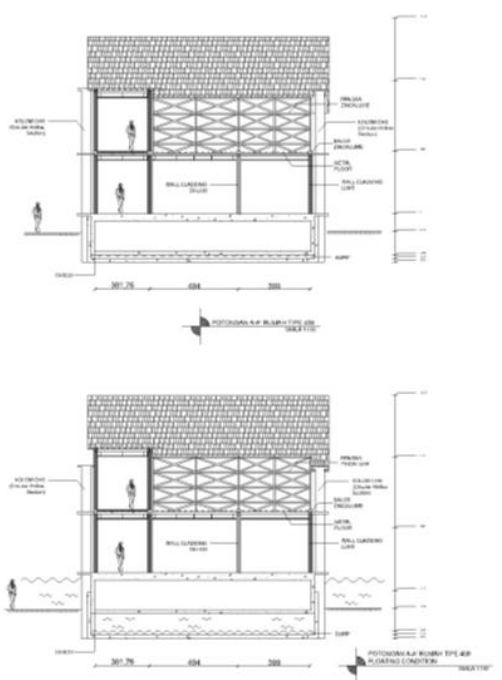

Gambar 10. Potongan A-A' 


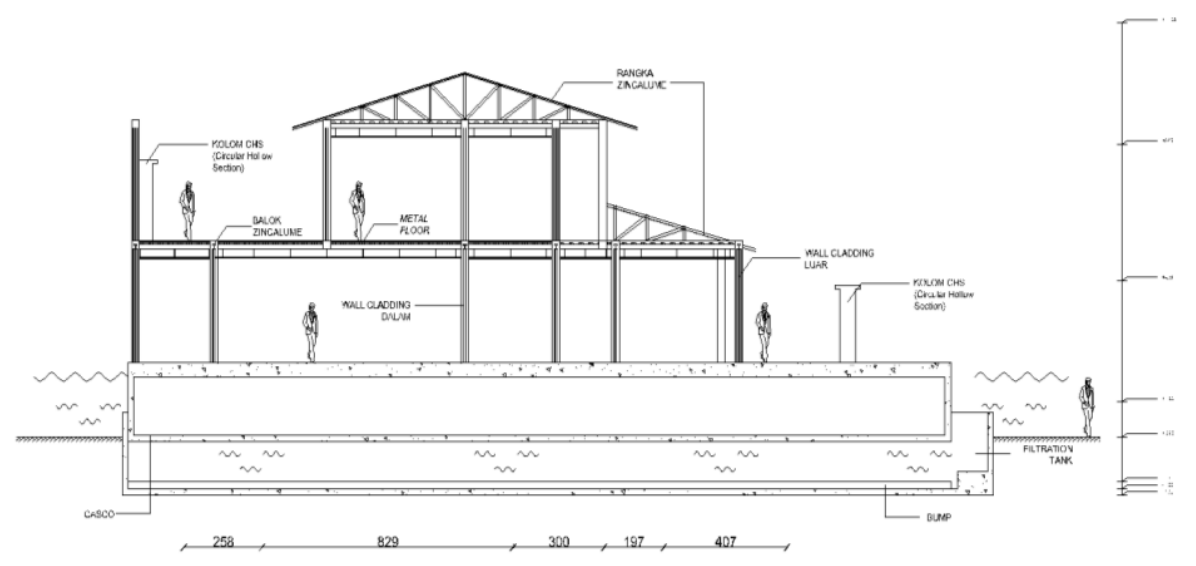

Gambar 11. Potongan B-B' Floating Condition

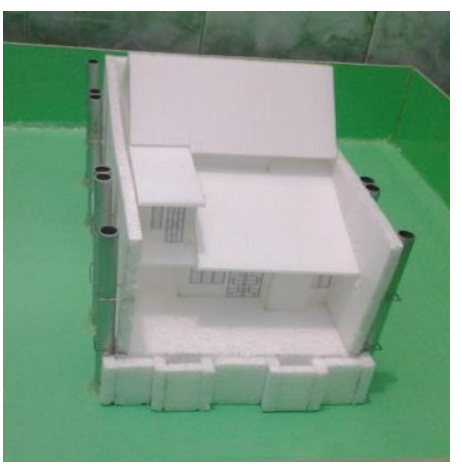

Gambar 12. Replika Bangunan pada Kondisi Normal

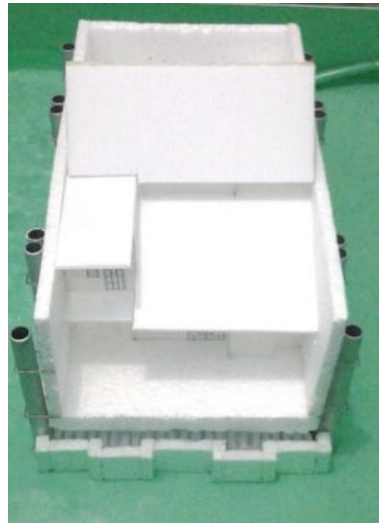

Gambar 13. Replika Bangunan pada Kondisi Floating

\section{KESIMPULAN}

Dari kajian ini dapat ditarik kesimpulan sebagai berikut:

1. Pendekatan penyelesaian masalah banjir pada kajian ini didekati dengan penyelesaian rekayasa sistem struktur bangunan. Teknologi floating platform dipilih sebagai salah satu alternatif solusi.

2. Keseluruhan konstruksi bangunan dibagi menjadi tiga bagian, yaitu substructure, middle structure, dan upper structure. Bangunan ini menggunakan material dengan bobot yang ringan agar memudahkan keseluruhan konstruksi bangunan dapat terapung. Pada bagian substructure terdapat casco, bump, dan slab yang menggunakan bahan beton prategang. Pada bagian middle structure menggunakan Circular Hollow Section sebagai kolom struktural dan baja ringan tipe Wf sebagai kolom praktisnya. Kolom struktural diperkuat dengan $X$ bracing structures guna mereduksi gaya lateral akibat banjir dan angin pantai. Wall cladding dengan jenis stoneveener dipilih sebagai penutup dinding interior dan jenis metalcladding sebagai penutup dinding eksteriornya. Bagian upper structure menggunakan bahan zincalume yang diperkuat dengan $x$ bracing tructures.

3. Sistem floating platform yang dipilih, diterapkan secara individual pada setiap bangunan di lokasi kajian, sehingga sangat memungkinkan untuk dapat diterapkan pada lokasi lain dengan kondisi tertentu. 


\section{Daftar Pustaka}

Ahmad, Aksan, Effendi, Hermawan (2009) Prof. Dr. Ir. Sedyatmo: Intuisi Mencetus Daya Cipta. Jakarta Selatan: PT Mizan Publika.

Davis, J., Han, D., Hu, Z., Lan, G., Maren, E., Twyman, C. (2002) Design Studies on Flood-Proof House. Bristol: Department of Civil Engineering University of Bristol.

Flexible for all sub-structures in new build or refurbishment, 2012.

http://www.kalzip.com), diakses 28 Oktober 2015.

Flexible Pipelines,

(http://anggraenieka.wordpress.com), diakses 11 November 2015.

Geografis Jakarta, 2009 (http://www.jakarta.go.id), diakses 18 Januari 2015.

Ismail, Z. B., Mohamad, M. I., Nekooie, M. A. (2012) Amphibious House, a Novel Practice as a Flood Mitigation Strategy in South-East Asia. Public Policy and Administration Research, 2 (1): 3-8.

Moan, T., Utsunomiya, T., Wang, C. D., Watanabe, E. (2004) Very Large Floating Structures: Applications, Analysis And Design. CORE Report, 2: 2-25.

Republik Indonesia (2014) Dinas Tata Ruang dan Tata Kota DKI Jakarta. Jakarta.

Tipe-Tipe Cladding atau Siding yang Paling Populer, 2013. (http://www.architectaria.com), diakses 29 Juli 2015.

Steel X-Bracing-Teknologi Bahan (2010) (http://www.winnerfirmansyah.wordpre ss.com), diakses 10 November 2015. 